\title{
The State of Air in the European Union and Quality of Europeans' Life
}

\begin{abstract}
This article aims to present the impact of air pollution on the quality of life of EU residents. With the aid of institutional-legal and statistical analysis an attempt has been undertaken to answer the following research questions: 1) negative concentrations whose pollution exceeds norms set out at EU levels, 2) causes of above-norm pollution concentrations and 3) impact of pollution on the health of Europeans. During the conducted research it was demonstrated that the quality of life of Europeans is being lowered by a continuing above-norm concentration of air pollution whose exposure is related to people feeling worse, numerous diseases related to the breathing system, circulation, nervous and even reproductive system as well as increased death rate and shortening of life expectancy. The estimated number of premature deaths in 2014 resulting from exposure to fine dust, ozone and carbon dioxide in the EU amounted to 487,600 . As the investigation shows, the best quality of life, taking into consideration air quality, is afforded by Finland, Ireland and Sweden.
\end{abstract}

Key words: ecological security, environmental security, health security, quality of life, air quality, European Union

$\mathbf{T}$ he quality of life is understood as "the degree of meeting material and non-material needs - fulfilling standards or realising values such as biological, psychological, spiritual, social and political, cultural, economic and ecological of individuals, families and the community" (Nowa encyklopedia powszechna PWN, 1997, p. 121; Encyklopedia PWN). It is not possible therefore to experience a high quality of life in a polluted environment, whose part - the atmosphere, is subjected to strong anthropogenic impact, especially as a result of burning fuels, power stations and power-heating plants, household fireplaces and in transport, technological and construction processes as well as the use of artificial fertilisers. The impact of air pollution on people's health became the object of interest on the part of public opinion after the occurrence in December 1952 of the great London Smog. In the space of five days as a result of respiratory tract infections, ischaemia and asphyxiation, approximately 4000 people died, while in the following months another 8000 as a result of respiratory tract diseases. The above was caused by a pocket of air together with its pollution from particulate matter, arising from the burning of coal in the three London power plants and in households attempting to heat their flats and houses at a time of extremely cold weather and sulphur dioxide emitted by various means of transport (Wojtalik, 2012).

Air pollution, that is all permanent substances of a liquid and gas nature whose emissions can be harmful to people's health or the environment, damage material goods or worsen their aesthetic qualities, continue to constitute a challenge for the majority of EU Member States, especially in urbanised areas (Poskrobko, Poskrobko, 2012, p. 195). According to the Organisation for Economic Co-operation and Development, (OECD), 
unless new initiatives are undertaken for the protection of the atmosphere from pollution, by 2015 the poor quality air will become the main environmental cause of death across the globe. According to the estimates of the above, premature deaths caused by exposure to breathing particulate matter could amount to 3.6 million people by 2050 - more than as a result of the lack of access to clean drinking water and washing facilities, or indeed malaria. In turn, exposure to ground-level ozone can cause the premature death of around 750,000 people (OECD, 2012, p. 276).

In EU environmental policy the protection of air quality from harmful pollution for people's health and the environment constitutes one of its fundamental pillars. The most important aspects of the protection of air quality are regulated in EU law and concern the definition of its standards and quality, the control of polluted emissions and the setting of respective country levels. European regulations impose the responsibility of formulating plans for the protection of air quality for areas where the concentration of pollution in the air exceeds normative values. In the space of 20 years in the EU a significant lowering of sulphur dioxide emissions has been observed - around $80 \%$ and that of nitrogen monoxide and volatile organic compounds - around 40 to 50\% (European Commission, 2016).

Nonetheless, the EU aims for the improvement of air quality to an extent where it is possible to reach concentrations of defined compounds below levels harmful for public health and the environment. A significant problem remains, as indicated in the $7^{\text {th }}$ Environment Action Programme of initiatives up to 2020, Living well, within the limits of our planet, remains 'a good quality of life taking into account the limitations of our planet', in particular the emission of particulates emitted into the air (particulate matter) dangerous for the health of EU residents and the pollution of the ozone, harming the human organism (Decision No. 1386/2013/EU, appx. 7, pt 44).

\section{The most significant air pollution in the $\mathrm{UE}$ and its source}

Acceptable levels of pollution considered as safe for people's health and environment in the EU as well as methods for their evaluation were defined in the Directive 2008/50/EC of the European Parliament and of the Council of 21 May 2008 on ambient air quality and cleaner air for Europe (OJ EU L 152/1, 11.06.2008), known as the CAFE ${ }^{1}$ Directive and Directive 2004/107/EC of the European Parliament and of the Council of 15 December 2004, relating to arsenic, cadmium, mercury, nickel and polycyclic aromatic hydrocarbons in ambient air (OJ EU L 23/3 26.01.2005). On account of the deleterious effects of air pollution on citizens' health in EU Member States and evaluation of their quality in respect to the contents of 11 substances is made: sulphur dioxide $\left(\mathrm{SO}_{2}\right)$, nitrogen dioxide $\left(\mathrm{NO}_{2}\right)$, carbon monoxide (CO), benzene $\left(\mathrm{C}_{6} \mathrm{H}_{6}\right)$, O zone $\left(\mathrm{O}_{3}\right)$ and particulate matter (PM10 i PM2.5), as well as heavy metals present in the latter $\mathrm{PM}_{10}$ such as lead $(\mathrm{Pb})$, arsenic (As), cadmium $(\mathrm{Cd})$, nickel $(\mathrm{Ni})$ and benzo(a)pyrene $\left(\mathrm{C}_{20} \mathrm{H}_{12}\right)$. Three particular substances are analysed in respect to the protection of plants: sulphur dioxide $\left(\mathrm{SO}_{2}\right)$, nitrogen monoxide $\left(\mathrm{NO}_{\mathrm{x}}\right)^{2}$ and ozone.

\footnotetext{
${ }^{1}$ The acronym CAFE stands for Directive on ambient air quality and cleaner air for Europe.

2 The high temperature at which mining fuels are burnt leads to a reaction between nitrogen and oxygen. Nitrogen oxide (NO) arises, which in the air oxidised into $\mathrm{NO}_{2}$. The value of these two oxides is therefore given in total and written as $\mathrm{NOx}\left(\mathrm{NO}_{\mathrm{x}}=\mathrm{NO}+\mathrm{NO}_{2}\right)$. See further: Juda-Rezler (2006), p. 59.
} 


\section{Particulate matter}

Particulate matter, (PM) it is a mixture of fine particulates and minute ambient liquid drops, which are pollutants equally, as initial, directly emitted into the atmosphere as well as secondary, arising in the atmosphere as a result of chemical reactions. Primary particulate matter has its origin in natural sources in the form of for example, forest fires, sea air, desert particulates, volcano eruptions, material of plant origin or that of animals as well as anthropogenic. As far as sources tied to the activities of man, in the main one can point to the processes of burning fuels, especially solid fuels and industrial processes. Further, significant amounts of particulates are emitted from the energy sector, mining, metallurgical, chemical, construction and transport, where the larger part of emissions arises from the friction of tyres, brakes and road surfaces as well as the urban-household sector. Secondary particulate matter arises as a consequence of the transformation of particulates $-\mathrm{SO}_{2}, \mathrm{NO}_{\mathrm{x}}$ and volatile organic compounds (VOC) (Kamiński, Strużewska, 2018, p. 7).

On account of the size of particulates there is a general division of particulate matter into fine, when particulates are smaller than $2.5 \mu \mathrm{m}$ and coarse for those larger than $2.5 \mu \mathrm{m}$. Particulate matter less than $10 \mu \mathrm{m}$ in diameter is able to adsorb heavy metals (lead, cadmium) and chemical compounds, in particular of organic origin, in the main belonging to polycyclic aromatic hydrocarbons (PAH) (Pałasz, 2016, p. 58). Table 1 presents a taxonomy of particulate matter together with their properties.

Table 1

Ambient particulate matter

\begin{tabular}{|l|l|l||}
\hline Diameter & Properties & \multicolumn{1}{c|}{ Properties } \\
\hline$>10 \mu \mathrm{m}$ & Very coarse & $\begin{array}{l}- \text { arise in a mechanical way as a result of friction or crumbling in various types } \\
\text { of materials such as the friction of tyres and brakes particulates of natural } \\
\text { origin such as sea salt, } \\
- \text { fall rapidly, } \\
- \text { easily removed from the atmosphere by processes of sedimentation and fall, } \\
- \text { have a limited radius of transfer, } \\
- \text { people near the source of emission are prone to their activity. }\end{array}$ \\
\hline $2.5-10 \mu \mathrm{m}$ & Coarse & $\begin{array}{l}- \text { mineral particles from production processes, construction work (i.e. demoli- } \\
\text { tion) and burning, } \\
- \text { biological particles, (the pollen of some plants, mushroom spores), } \\
- \text { ambient for short periods (after several hours), } \\
- \text { easily removed from the atmosphere as a result of sedimentation processes } \\
\text { and with showers, } \\
- \text { carried mainly short distances (from several to several hundred kilometers). }\end{array}$ \\
\hline$\leq 2.5 \mu \mathrm{m}$ & Fine & $\begin{array}{l}- \text { result from burning (wood and mined fuels), agricultural or industrial work } \\
\text { and technological processes, } \\
- \text { ambient for relatively long periods (from days to weeks), } \\
- \text { May be carried for hundreds and thousands of kilometers. }\end{array}$ \\
\hline$\leq 0.1 \mu \mathrm{m}$ & Very fine & $\begin{array}{l}- \text { emitted mainly in burning processes, } \\
- \text { ambient for very short periods (from minutes to hours), } \\
- \text { can be transported for tens of kilometers, } \\
- \text { their concentration falls quickly as a result of dilution. }\end{array}$ \\
\hline
\end{tabular}

Source: Author's taxonomy based on M. Reizer, Co to jest pyt zawieszony?, in: Pyty drobne $w$ atmosferze. Kompendium wiedzy o zanieczyszczeniu powietrza pytem zawieszonym $w$ Polsce, eds. K. Juda-Rezler, B. Toczko, Główny Inspektorat Ochrony Środowiska, Warszawa 2016, pp. 12-14. 
In 2015 in the $\mathrm{EU} 42 \% \mathrm{PM}_{10}$ was emitted by households and buildings belonging to public institutions and business, while $17 \%$ arose from industrial processes, $15 \%$ from the agricultural sector, $11 \%$ Road transport, $5 \%$ burning fuels and industry, $5 \%$ in the production of energy and its distribution, $3 \%$ rubbish tips and $2 \%$ from transport other than road (European Environment Agency, 2017a, p. 22). The total emission of PM10 in the UE for 2016 in respect to the year 2000 fell by $26 \%$, from 2,783 Gg two 2,064 Gg. The greatest reduction of emissions was attained by Malta (75\%), Estonia (65\%), Cyprus (58\%), Greece (43\%) and France (42\%). In the above-mentioned period emissions increased in Lithuania (38\%), Romania (21\%), Slovenia (12\%) and Bulgaria (2\%). The greatest contribution in total emissions in the EU (above 10\% total emissions), according to latest data available for 2016 had Poland $(12.6 \%-259 \mathrm{Gg})$ and France $(12.4 \%$ $-255 \mathrm{Gg}$ ). It should be noted however, that France's contribution for total emissions for 2016 in comparison to that of the year 2000 decreased by $3.4 \%$, whereas in the case of Poland it rose by 1.5\% (European Environment Agency, 2018, p. 61).

The source of $\mathrm{PM}_{2.5}$ emissions in 2015 in the UE had the following forms: 57\% fine particulate matter was emitted by households, buildings of public institutions and business, $11 \%$ came from road transport, $10 \%$ from industrial processes, $7 \%$ burning fuels in industry, $5 \%$ from the production of energy and its distribution, $4 \%$ from agriculture, $4 \%$ rubbish tips and 2\% from transport other than (European Environment Agency, 2017a, p. 22). In the period 2000-2016 the total emission of $\mathrm{PM}_{2.5}$ in the UE fell by approximately $28 \%$ - from $1,861 \mathrm{Gg}$ to $1,343 \mathrm{Gg}$. Malta, the Netherlands, Greece, Cyprus, France and Croatia were the countries that in the space of 17 years were able to lower the most emissions of fine particulates respectively by $74,57,55,48$ and $45 \%$. Only in four countries: Bulgaria, Romania, Slovenia and Hungary did the emission of $\mathrm{PM}_{2.5}$ increase, respectively by $24,17,17$ and $10 \%$. In 2016 the greatest, more than $10 \%$ contribution in emissions from the EU occurred in France $(12.7 \%-170 \mathrm{Gg})$, Italy $(12 \%-162 \mathrm{Gg})$ and Poland $(10.8 \%$ - $146 \mathrm{Gg})$ (European Environment Agency, 2018, p. 59). The sources of emission of the most significant precursors to particulate matter in the UE, which are nitrogen oxide and sulphur dioxide, are discussed in a subsequent part of the article.

The binding norms in the European Union for $\mathrm{PM}_{10}$ is the acceptable average daily value of $50 \mu \mathrm{g} / \mathrm{m}^{3}$, which cannot be exceeded more than 35 times in the course of a year and the average yearly value at the level of $40 \mu \mathrm{g} / \mathrm{m}^{3}$. Member States have agreed to maintain both of these standards as of 2005, though in 2015 19\% of measuring stations in the EU recorded more than 35 days where average daily norms were exceeded in 20 Member States - a 95\% in urban areas or outer urban. The largest breaks of pollution thresholds took place in Bulgaria, Poland and Italy. The concentration of PM10 above average annual was recorded by $3 \%$ of measuring stations, first and foremost in three countries: Bulgaria, Poland and Italy. Moreover, at least one station reordered a breaking of thresholds in the Czech Republic, Cyprus, France, Greece, Spain and Hungary. In addition, taking into account the more restrictive proposals of the World Health Organization (WHO), which were presented for the above-mentioned in the publication of pollution in Table 2, the average annual norm was exceeded in 54\% of measuring stations, in all EU Member States apart from Estonia and Ireland (European Environment Agency, 2017a, p. 31, 33). According to the wording of the CAFE Directive, the EU in establish- 
ing aims in respect to the quality of air should take into account the WHO norms and therefore one should expect a tightening of these standards at the EU level.

For the particulate $\mathrm{PM}_{2.5}$ in the UE a norm was defined in the form of average annual values amounting to $25 \mu \mathrm{g} / \mathrm{m}^{3}$, which should not be exceeded from 2015 and $20 \mu \mathrm{g} /$ $\mathrm{m}^{3}$ from 2020. At present, three Member States have not reached the binding standard established in 2015 - Poland, Czech Republic and Italy. Some 93\% of thresholds that were exceeded took place in urban or outer urban areas, affecting $6 \%$ of all UE measuring stations. Taking into account the average annual recommendation of WHO for $\mathrm{PM}_{2.5}$ amounting to $10 \mu \mathrm{g} / \mathrm{m}^{3}, 75 \%$ of stations recorded thresholds being exceeded. Air quality fulfilling WHO norms was experienced only by the residents of Estonia, Finland, Ireland and Sweden (European Environment Agency, 2017a, p. 33 and 35).

As a consequence of exceeding EU norms in respect of the quality of air regarding particulate matter, the European Commission in September 2015 brought against Bulgaria and in December the same year also Poland, a complaint to the Court of Justice of the European Union (CJEU) in Luxembourg. Both countries were found guilty of breaking EU law. CJEU judges found that Bulgaria from 2007 to at least 2013 included and Poland from 2007 to at least 2013, systematically did not abide by acceptable average daily norms (respectively in five and in thirty-five areas of assessment) and average annual norms (respectively in five and nine areas of assessment) of $\mathrm{PM}_{10}$ concentration values and did not undertake the necessary action to mitigate thresholds being broken in the shortest possible time (judgment of the Court of Justice of the European Union, 5 April 2017, ECLI:EU:C:2017:267 and judgment of the Court of Justice of the European Union 22 February 2018, ECLI:EU:C:2018:94).

In January 2018 a meeting took place between the EU Commissioner for the environment, Karmenu Vella, and the ministers for the environment of nine Member States: Czech Republic, France, Spain, Germany, Romania, Slovakia, Hungary, Great Britain and Italy in respect to the breaking of thresholds in respect to air quality. The European Commission therefore announced that should the situation in this matter not improve in respect of the above-mentioned countries, it shall bring these Member States to the EU Court of Justice in this matter (Bodalska, 31.01.2018).

\section{Tropospheric ozone}

Ozone is a colourless gas composed of three oxygen atoms $\left(\mathrm{O}_{3}\right)$, which in the atmosphere constitutes the main oxidising compound. Approximately $90 \%$ of atmospheric ozone occurs in the ozone sphere - a layer of the stratosphere at a height of 10 to $50 \mathrm{~km}$ above the surface of the Earth, where for the main part it absorbs ultraviolet radiation harmful to living organisms. Ozone in the lower layer of the atmosphere - troposphere, constitutes secondary pollution and arises under the influence of solar activity from ultraviolet radiation on nitrogen oxide $\left(\mathrm{NO}_{\mathrm{x}}\right)$ in the presence of compounds containing carbon such as: carbon monoxide (CO), arising mainly from the energy and urban-household sectors, methane $\left(\mathrm{CH}_{4}\right)$ emitted by the mining industry, during distribution of fuels, agriculture and rubbish tips as well as non-methane volatile organic compounds (NMVOC) originating in the transport and industry sectors as a result of burning mining fuels or 
the use of solvents (Juda-Rezler, 2006, pp. 50-51). Ozone in this situation is known as tropospheric, surface-level or ground-level.

Episodes of sudden and very high concentrations of ozone are known as photochemical, summer or Los Angeles smog. These are formed over large urban agglomerations, where foremost there are many precursors of ozone emitted $\left(\mathrm{NO}_{x}, \mathrm{CO}, \mathrm{VOC}\right)$ from the transport sector, which are the source of smog. The above occurs during summer, spring, during warm and hot (temperatures between $25-35^{\circ} \mathrm{C}$ ), windless and damp days - in the case of Europe from June to September (Główny Inspektorat Ochrony Środowiska, 2016). The phenomenon of smog is reinforced by very tall urban architecture, which creates a barrier in the distribution of pollution arising from communication routes as well as geographical aspects such as depressions or encircling mountains where towns are situated.

The acceptable level of eight-hour concentrations for ground-level ozone in respect to protecting people's health, binding for Member States as of 2010, amounts to $120 \mu \mathrm{g} / \mathrm{m}^{3}$ and in a calendar year must not be exceeded more than 25 times. In the EU a concentration norm for tropospheric ozone was also set for plant protection. Moreover, for the purposes of long-term goals a level was defined below which, according to the state of contemporary knowledge, a direct harmful impact on the health of people or the environment as a whole is not likely (Ustawa Prawo ochrony środowiska [Protection of the Environment Bill], Journal of Laws from 2001, No. 62, item 627). It was accepted that from 2020 the measure of eight-hour concentration will not be exceeded in any case. WHO also defined a recommended eight-hour concentration for the ozone in respect to people's health - at the level of $100 \mu \mathrm{g} / \mathrm{m}^{3}$ (World Health Organization, 2006, p. 14). In all, 18 EU Member States recorded excess levels of acceptable concentration levels on more than 25 occasions. Countries that exceeded such thresholds were Italy, Germany, France and Poland. In this context some $41 \%$ of measuring stations recorded excess levels of polluted ozone concentrations. The quality of air according to WHO norms was only met by 4\% of measuring stations (European Environment Agency, 2017a, p. 39).

\section{Nitrogen dioxide and sulphur dioxide}

Nitrogen dioxide $\left(\mathrm{NO}_{2}\right)$ is a red-brown, poisonous gas that finds difficulty in dissolving in water. Nitrogen oxides arises naturally in the atmosphere as a result of volcanic eruptions, processes arising in the oceans and soil in the context of nitrogen circulation in nature as well as photo-oxidation of nitrogen, and as a consequence of man's activity. The source of anthropogenic emissions is burning mining fuels at a high temperature (Juda-Rezler 2006, pp. 58-59). Nitrogen dioxide is present in the atmosphere for between 20 and 100 years (Janka, 2014, p. 18). In the EU the greatest sources of such emissions from man's activity are road transport (39\% total emissions in 2015), the production of energy and its distribution (19\%), households, buildings of public institutions and commercial premises (14\%) as well as the use of energy in industry (12\%) (European Environment Agency, 2017a, p. 22). In the space of 27 years (between 1990 and 2016) the emission of $\mathrm{NO}_{\mathrm{x}}$ fell in every EU Member State and as a whole in the EU significantly - by $58 \%$, from 18,139 to $7,644 \mathrm{Gg}$. The greatest reductions of emissions 
were attained by the Czech Republic (80\%), Great Britain (72\%), Slovakia (69\%) and Italy (63\%) (European Environment Agency, 2018, p. 49).

The respective norms binding in the EU from 2010 for nitrogen dioxide in respect to the protection of health, in accord with the recommendations of WHO, are at a level acceptable for one-hour concentrations amounting to $200 \mu \mathrm{g} / \mathrm{m}^{3}$, which cannot be exceeded more than 18 times in the course of a year and average annual values at a level of $40 \mu \mathrm{g} / \mathrm{m}^{3}$. In 2015, in 22 EU Member States the average annual norms in this respect were exceeded. Among those that emit the most nitrogen dioxide $-10 \%$ or more emissions are Germany (15.9\%), Great Britain (12\%), France (11\%), Spain (10\%) and Italy (10\%). In 2016 Denmark, Ireland, Germany, Poland and Slovenia recorded greater concentrations of $\mathrm{NO}_{\mathrm{x}}$ than in the previous year (European Environment Agency, 2018, p. 49). The harmful impact of nitrogen dioxide on plants resulted in the establishment of also an average annual level acceptable for their protection amounting to $30 \mu \mathrm{g} / \mathrm{m}^{3}$.

Sulphur dioxide $\left(\mathrm{SO}_{2}\right)$ is a colourless gas, which is poisonous for people and animals as well as being harmful for plants. It is characterised by a high degree of solvency in water. In the air it reacts with steam from water, constituting as a consequence the main course of acid rain arising. It also arises from natural sources such as the explosion of volcanoes, disintegration of volcanic matter processes, forest fires and the erosion of soils as well as anthropogenic reasons - first and foremost from the burning of mining fuels polluted by sulphur such as coal and crude oil. The consequences of a significant amount of $\mathrm{SO}_{2}$ emissions from energy sources of tall chimney stacks are often its transport over long distances (Juda-Rezler, 2006, p. 44). In the EU sulphur oxides in the main arise from the production of energy and its distribution (59\% w $2015 \mathrm{r}$.), use of energy and industry (19\%), households, buildings of public institutions and commercial premises (13\%) as well as industrial processes (7\%) (European Environment Agency, 2017a, p. 22). The limitation of sulphur dioxide emissions in the EU should be recognised as highly effective. Between 1990 and 2016 such emissions fell by 91\%, from 25,078 Gg two 2,378 Gg (European Environment Agency, 2018, p. 54).

For the purposes of protecting health, the EU defined an acceptable level of one-hour concentrations of sulphur dioxide at the level of $350 \mu \mathrm{g} / \mathrm{m}^{3}$, which must not be exceeded more than 24 times in the course of a year. Moreover, Member States are bound to observe an acceptable level of average daily concentrations of $\mathrm{SO}_{2}$ amounting to $125 \mu \mathrm{g} / \mathrm{m}^{3}$ with the number of such thresholds being broken in the course of the year is not more than three. These norms have been binding since 2005. In 2015, two stations, in Bulgaria and France, recorded thresholds being broken of both the above acceptable levels. The recommendations of WHO for average daily concentrations are six times lower, amounting to $20 \mu \mathrm{g} / \mathrm{m}^{3}$ (European Environment Agency, 2017a, p. 45). EU Member States responsible for the emission of the most sulphur dioxide are Poland $(582 \mathrm{Gg}$, constituting $24.5 \%$ of emissions in 2016), Germany (356 Gg, 15\%) and Spain (218 Gg, 9.2\%). In 2016 in Belgium, Denmark, Greece, Sweden and Cyprus there was an increase of $\mathrm{SO}_{\mathrm{x}}$ emissions in respect to 2015 (European Environment Agency, 2018, p. 54). In respect to the protection of plants, the EU also defined the acceptable level of average daily concentrations of $\mathrm{SO}_{2}$, which are in line with the recommendations of WHO, amounting to $20 \mu \mathrm{g} / \mathrm{m}^{3}$. Moreover, the above level of sulphur dioxide concentrations cannot be exceeded during winter, that is the heating season, from October 1 to March 31. 
The success of the $\mathrm{EU}$ and limiting emissions of $\mathrm{SO}_{2}$ and (though to a lesser degree in respect to the continuous growth of the numbers of motor cars) $\mathrm{NO}_{2}$ is a consequence of the introduction of what has become known as the ceiling directive 2001/81/ WE in respect to country levels of emission for some types of air pollution (OJ EU L 309, 27.01.2001). The above binds Member States to a differentiation of ceilings for the emission of four types of pollution transported at long distance, including both of the above mentioned gases, from all sources in the EU apart from international maritime waterways and emissions from civil aviation, but with taking into account emissions associated with landing and starting of airplanes. The given limits were to be reached in 2010 and in subsequent years maintained, which is being realised by Member States. The directive was treated as an acquis communautaire, as a consequence of which countries entering the EU after its introduction are also bound to preserve defined ceilings of carbon dioxide, nitrogen dioxide, ammonia and NMVOC emissions (Raport, 2011, p. 2).

\section{Air pollution and its conseqences for peoples' health}

Pollution from air can permeate into the organism of a person through their respiratory tract, digestive track and permeate through the skin. Further, it has a negative influence on the respiratory tract, circulation, nervous and reproductive systems. Those that are particularly at risk are children, the elderly and individuals with diseases of the respiratory tract and circulation system. The former are more sensitive to pollution for they breathe in approximately $50 \%$ less air per kilogram of body mass than adults and at the same time, spend more time outdoors. Their respiratory tract is still immature and their defence system weaker than is the case in adults. Exposure therefore to pollution in the air is tied with an increased death rate and shortening of expected life expectancy. In the EU the estimated number of premature deaths in 2012 as a consequence of exposure to $\mathrm{PM}_{2.5}, \mathrm{O}_{3}$ and $\mathrm{NO}_{2}$ amounted to 491,000 (European Environment Agency, 2015, p. 44) and in 2014 487,600 (European Environment Agency, 2017, p. 56).

In towns and cities with a large intensity of road traffic, exposure to particulate matter is often correlated with exposure to other forms of pollution - especially nitrogen dioxide and carbon monoxide (CO), which makes difficult formulating a specific indication of the impact of each of these forms of pollution. In spite of this, thanks to various forms of research such as epidemiological, clinical and toxicological first and foremost in Europe, the United States and Canada, it is possible to ascribe particular forms of pollution to specific forms of impact on people's health. Thus particulates because of their differentiated health have effects relative to their size at the level of concentration and chemical composition. Particulates of a diameter measuring $2.5-10 \mu \mathrm{m}$ can accumulate in the upper respiratory tract and cause coughs, whistling breath and dyspnoea. This leads to the exacerbation of chronic diseases such as asthma or Chronic Obstructive Pulmonary Disorder (COPD). ${ }^{3}$ Moreover, they are responsible for lower indicators of lung

\footnotetext{
${ }^{3}$ As a result of COPD there is a partial limitation of the passage of air of the respiratory tract, which is associated with a chronic inflammatory reaction of the respiratory tract to harmful substances. See further: Jędrak, Konduracka, 2017, pp. 44-47.
} 
activity, which in turn increases the risk of COPD occurring in future (Krzyżanowski, 2016, pp. 17, 19-20).

Fine and very fine particulates accumulated in the lower respiratory tracts cause damage and a lessening of the surface of gas exchange in the lungs. Particulates of a diameter less than $2.5 \mu \mathrm{g} / \mathrm{m}^{3}$ therefore, cause chronic inflammation around respiratory tracts. Very fine particulate matter permeate through the wall of the lung alveoli into the circulatory system, interact with the endothelium of blood vessels, initiating the growth of an atherosclerotic plaque, ${ }^{4}$ and as a result lead to dysfunctions of the heart's rhythm, ischaemia and high blood pressure. The consequences of every growth in the concentration of fine particulates measuring $10 \mu \mathrm{g} / \mathrm{m}^{3}$ is the growth in the number of hospitalisations as a result of infarctions by $0.8 \%$ as a result of ischaemia of $0.7 \%$. Increased exposure to $\mathrm{PM}_{2.5}$ for several hours up to several weeks may result in a heart attack (infarction), stroke, or even death (Mazurek, 2018, pp. 26-27). In Europe over $3 \%$ of deaths from diseases of the circulatory or system is caused by particulate matter (Milanowski, 2018, p. 11).

Particulate matter also has a negative influence on the nervous system. Very fine particulates that enter the blood vessels from the lungs reach various organs, including the brain. These may cause headaches, anxiety, hyperactivity, problems with concentration, dementia, Parkinson's disease, dysfunction of cognitive processes and memory in children and youth, and increase the tendency towards aggressive behaviour. The significant interdependence between concentrations of $\mathrm{PM}_{10}, \mathrm{NO}_{2}, \mathrm{SO}_{2}$ and $\mathrm{CO}$ and the number of suicide attempts in Vancouver and the number of cases of depression brought to hospitals in seven Canadian towns has been proved statistically (Jędrak, Konduracka, 2017, p. 74, 76, 78).

The agenda of WHO and International Agency for Research on Cancer, IARC in 2013 found that external air pollution in general is the cause of lung cancer and a factor increasing the risk the occurrence of a cancer of the urinary bladder. In 2010, 223,000 (15\% deaths were ascribed to cancer of the lung. Research in respect to the influence on people's health of just particulate matter led to its classification by the IARC as being carcinogenic (IARC, 2016, p. 34). On the basis of long-term research conducted in the USA, Western Europe and Japan, it is claimed that together with a growth of ever $10 \mu \mathrm{g} / \mathrm{m}^{3}$ long-term exposure of a person's organism to $\mathrm{PM}_{2.5}$ and $\mathrm{NO}_{2}$, the incidence of lung cancer increases respectively by $9 \%$ and $4 \%$ (Jędrak, Konduracka, 2017, p. 54).

Fine particulate matter can permeate through the placenta and be responsible for congenital defects in the embryo. Above-normative concentrations of $\mathrm{PM}_{2.5}$ result in the worsening of such parameters as weight at birth, length of the body and natal circumference of the head, which are associated with a weekly developed effectiveness and functioning of various systems, including the immunological. The consequences of a lowered resistance are the children's predilection to recurrent diseases of the respiratory tract (inflammation of the bronchi and pneumonia). Further, the negative influence of fine particulates on the development of the nervous system of children born to women exposed to compounds from the PAH group (components of particulate matter) has been

${ }^{4}$ The atherosclerotic plaque is a change created in the external membrane of arteries, decreasing their diameter. For more on the subject of arthrosclerosis see: Szczeklik, Gajewski, 2014, p. 160. 
confirmed. In the research conducted in Kraków, the children concerned had an intelligence quotient lower on average by 3.8 points on the IQ scale in comparison to children of mothers living in an environment with cleaner air (though not free of fine particulates) (Jędrychowski, Majewska, pp. 2, 6, 8-9).

Long-term, over several years, exposure to fine particulate matter, occurring among others in Poland or Bulgaria, can lead to an abbreviation of the expected life expectancy by several months or even years. The European Environment Agency has estimated that in EU Member States anthropogenic emissions of $\mathrm{PM}_{2.5}$ are responsible for a shortening of life by an average of 8.5 months. In the 2014 such emissions were the cause of 399,000 premature deaths, including: 66,080 in Germany, 59,630 in Italy, 46,020 in Poland, 37,600 in Great Britain and 34,800 in France. The greatest number of deaths per capita was recorded in Bulgaria, Poland, Hungary and in Romania, while the lowest was noted in Ireland, Sweden and Finland (European Environment Agency, 2017, pp. 56-58).

The harmful effects on people's health can also be seen in the case of raised concentrations of gas pollution, including tropospheric ozone and dioxides of nitrogen and sulphur. Ozone, similar to nitrogen dioxide, does not react well with water, which leads to imposing a negative effect on the entire respiratory tract. The first symptoms of exposure to the effects of ground-level ozone are cough, itching in the throat and sleepiness as well as headaches. Excessive exposure in this context can result in a fall of blood pressure, inflammations of the eye and respiratory tract diseases such as pneumonia, fall in lung capacity and intensification of the symptoms of asthma. The human organism, defending itself from ozone entering the lungs, lowers the amount of oxygen intake, which may lead to an intensification of diseases of the circulation system (Albiniak, Czajka, 2017, p. 31). Further, ozone can be carcinogenic as research would seem to indicate (Wojewódzki Inspektorat Ochrony Środowiska, 2015). The number of premature deaths in the EU ascribed to the pollution of the ozone amounted in 2014 to 13,600: 2,900 in Italy, 2,200 in Germany, 1,630 in France, and 1,600 in Spain. Per capita, the most serious situation was recorded in Greece, Italy, Malta and Croatia, whereas the lowest number of deaths in this context took place in Ireland, Finland and Great Britain (European Environment Agency, 2017, p. 57 and 58).

Moreover, nitrogen oxides cause an aggravation of the mucous membranes of the throat, while in greater concentrations, death. Nitrogen oxide absorbed by the human organism reacts with haemoglobins and inside the tissues quickly oxidises into nitrogen dioxide. The symptoms of poisoning by nitrogen oxide are a general weakening of the organism, dizziness and numbness of the lower limbs. In the case of high doses of poisoning there occurs cyanosis of the mouth, weakening pulse and shivering. $\mathrm{NO}_{2}$ as a rule does not occur independently and its impact on the human organism depends on accompanying compounds. It causes dizziness and headaches and dilates the blood vessels, which causes a fall in blood pressure. In low concentrations it leads to the irritation of the respiratory tract and eyes, whereas in large such doses to oedema of the lungs, weakening pulse and degeneration of the heart muscle as well as a narcotic effect on the nervous system (Mysłowski, 2011, p. 37). Prenatal exposure to nitrogen dioxide can cause retardation in the intellectual development of a child (Mazurek, 2018, p. 33). 
The IARC in 2012 entered the fumes emitted by diesel engines (containing significant amounts of $\mathrm{NO}_{2}$ ) onto the list of carcinogenic compounds (IARC, 2012). It is not nitrogen dioxide alone that is responsible for cancer but other substances that are correlated with it such as VOCs, very fine particulate matter and polycyclic aromatic carbohydrates $(\mathrm{PAH})$ that are found in diesel fumes. It has been proven that together with every growth of $10 \mu \mathrm{g} / \mathrm{m}^{3}$ in respect to a long-term exposure of the human organism to $\mathrm{NO}_{2}$ the incidence of lung cancer increases by $4 \%$. Research has also shown that exposure on the part of adults to nitrogen dioxide in their place of residence is tied to an increased risk of the occurrence of brain tumours and cervical cancer. Children in turn, whose mothers during pregnancy were exposed to inhalation of nitrogen dioxide, were shown to fall ill more often to cancers in early childhood (Jędrak, Konduracka, 2017a, p. 54 and 57). The number of premature deaths in the EU ascribed to air pollution in respect to $\mathrm{NO}_{2}$ in 2014 amounted to 75,000: 17,290 in Italy, 14,500 in Great Britain, 12,860 in Germany and 9,330 in France. The greatest losses of human life with reference to population occurred in Italy, Great Britain, Belgium, Germany and Greece, the Netherlands and Spain. Those in Ireland, Finland, Estonia and Sweden breathed air least polluted by nitrogen dioxide (European Environment Agency, 2017, pp. 57-58).

Sulphur dioxide is absorbed by the upper section of the respiratory tract and from there reaches the blood circulation. It can cause a feeling of malaise and irritates the throat and eyes. Exposure to high concentrations of this gas can lead to chronic bronchitis, intensification of diseases of circulation system and a lowered resistance on the part of the lungs to infections - especially among children and the elderly. The greatest threat to human health is the occurrence in winter of episodes of very high concentrations of sulphur dioxide, fine particulate matter and organic compounds known as London Smog or Black Smog (Kozłowska-Szczęsna, Krawczyk, 2004, p. 44). High concentrations of $\mathrm{SO}_{2}(400-500 \mathrm{ppm})$ can lead to spasms of the glottis and oedema of the larynx or heart failure, which leads to sudden death (Mysłowski, p. 38).

\section{Conclusions}

The state of air is a key to the quality of life of every person, foremost in respect to the unfavourable consequences of health that its pollution causes. Health, according to the definition of WHO is "A state of complete physical, mental and social well-being and not merely the absence of disease or infirmity" (World Health Organization, 1946, p. 1). The aspects of pollution discussed in this article can significantly worsen the physical state of a person's organism, leading to a shortened life expectancy, while particulate matter, nitrogen and sulphur dioxides cause dysfunctions in the nervous system. Moreover, pollution in the atmosphere has a negative impact on the environment, limiting the potential of using its natural elements such as forests. The quality of air in the EU is slowly improving though a significant proportion of the urban population is exposed to above-normative concentrations of some of the air pollution such as particulates or ground-level ozone. The number of people living in areas of poor air quality is significantly greater when one considers the recommendations of WHO as shown in Table 2 for the period 2013 to 2015 . 
Percentage of the urban population in the EU exposed to air pollutant concentrations above certain EU and WHO reference concentrations

(minimum and maximum observed between 2013 and 2015)

\begin{tabular}{|l|c|c|c|c||}
\hline \multicolumn{1}{|c|}{ Pollutant } & $\begin{array}{c}\text { EU reference } \\
\text { value }\left(\boldsymbol{\mu g} / \mathbf{m}^{\mathbf{3}}\right)\end{array}$ & $\begin{array}{c}\text { Exposure estimate } \\
\mathbf{( \% )}\end{array}$ & $\begin{array}{c}\text { WHO guideline } \\
\left(\boldsymbol{\mu g} / \mathbf{m}^{\mathbf{3}}\right)\end{array}$ & $\begin{array}{c}\text { Exposure estimate } \\
\mathbf{( \% )}\end{array}$ \\
\hline $\mathrm{PM}_{2.5}$ & rok $(25)$ & $7-8$ & rok $(10)$ & $82-85$ \\
\hline $\mathrm{PM}_{10}$ & dzień $(50)$ & $16-20$ & rok $(20)$ & $50-62$ \\
\hline $\mathrm{O}_{3}$ & 8 godzin $(120)$ & $7-30$ & 8 godzin $(100)$ & $95-98$ \\
\hline $\mathrm{NO}_{2}$ & rok $(40)$ & $7-9$ & rok $(40)$ & $7-9$ \\
\hline $\mathrm{SO}_{2}$ & dzień $(125)$ & $<1$ & dzień $(20)$ & $20-38$ \\
\hline
\end{tabular}

Source: Author's taxonomy based on European Environment Agency (2017b), Exceedance of air quality standards in urban areas, Copenhagen, p. 6; Directive 2008/50/EC of the European Parliament and of the Council of 21 May 2008 on ambient air quality and cleaner air for Europe, appx. VII, XI, XIV \& World Health Organization (2006), WHO Air quality guidelines for particulate matter, ozone, nitrogen dioxide and sulfur dioxide. Global update 2005. Summary of risk assessment, Geneva, pp. 9, 14, 16, 18.

Despite noted, continued lowering levels of pollution in the EU, their normative values, first and foremost particular matter, continue not to be observed by many Member States such as the Czech Republic, Germany or Italy. There is cause to assume that calls on the part of the European Commission for a quick introduction of remedial action in this respect will not bring results and therefore complaints will be brought before the EUJC in respect to a breach of obligations concerning the Directive on quality of air and clean air in Europe. Further, both Bulgaria and Poland, already found guilty of breaching the above-mentioned directive as a result of exceeding thresholds concerning quality of air norms for particulate matter $\mathrm{PM}_{10}$, testifying to a lack of undertakings for sufficient remedial action, face the threat of high fines. ${ }^{5}$ It would appear therefore that only an imposition of financial penalties by the EUCJ may provide the impetus for Member States to introduce systemic solutions for cleaner air such as for example, in Poland establishing at a national level quality standards of solid fuels where they are yet to be introduced.

\section{Bibliography}

Albiniak B., Czajka J. (2017), Stan środowiska w Polsce. Sygnały 2016, Główny Inspektorat Ochrony Środowiska, Warszawa.

Bodalska B. (2018), Kary dla kolejnych państw za zanieczyszczanie powietrza?, Euroactiv, 31.01.2018, https://www.euractiv.pl/section/energia-i-srodowisko/news/47520/, 23.07.2018.

Decision No. 1386/2013/EU of the European Parliament and of the Council, of 20 November 2013 on a General Union Environment Action Programme to 2020 'Living well, within the limits to our planet', OJ EU L 354/171, 28.12.2013.

Directive 2004/107/EC of the European Parliament and of the Council of 15 December 2004 relating to arsenic, cadmium, mercury, nickel and polycyclic aromatic hydrocarbons in ambient air, OJ EU L 23/3, 26.01.2005.

Directive 2008/50/EC of the European Parliament and of the Council of 21 May 2008 on ambient air quality and cleaner air for Europe, OJ EU L 152/1, 11.06.2008.

5 The Supreme Audit Office has estimated possible fines for Poland at a maximum of 4 billion PLN.

See further: Supreme Audit Office (2014), p. 24. 
Encyklopedia PWN, https://encyklopedia.pwn.pl/haslo/jakosc-zycia;3916390.html, 17.07.2018.

European Commission (2016), Fact Sheet, EU approves new rules for Member States to drastically cut air pollution, 14 December 2016, Brussels, http://europa.eu/rapid/press-release_MEMO16-4372 en.htm, 23.07.2018.

European Environment Agency (2015), Air Quality in Europe - 2015 report, Publication Office of the European Union, Luxembourg.

European Environment Agency (2017a), Air Quality in Europe - 2017 report, Publication Office of the European Union, Luxembourg.

European Environment Agency (2017b), Exceedance of air quality standards in urban areas, https:// www.eea.europa.eu/data-and-maps/indicators/exceedance-of-air-quality-limit-3/assessment-3, 8.08.2018.

European Environment Agency (2018), European Union emission inventory report 1990-2016 under the UNECE Convention on Long-range Transboundary Air Pollution (LRTAP), Publication Office of the European Union, Luxembourg.

Główny Inspektorat Ochrony Środowiska (2016), Ozon - dobry i zły, 24.06.2016, http://www.gios.gov. pl/pl/aktualnosci/344-ozon-dobry-i-zly, 23.07.2018.

IARC, Internationl Agency for Research on Cancer (2012), Diesel engine exhaust carcinogenic, press release no. 213, 12 June 2012, https://www.iarc.fr/en/media-centre/pr/2012/pdfs/pr213_E.pdf, 7.08.2017.

IARC (2016), Outdoor Air Pollution. IARC Monographs on the Evaluation of Carcinogenic Risks to Humans, vol. 109, Lyon.

Janka R. M. (2014), Zanieczyszczenia pyłowe i gazowe: podstawy obliczania i sterowania poziomem emisji, Wydawnictwo Naukowe PWN, Warszawa.

Jędrak J., Konduracka E. (2017), Wpływ zanieczyszczeń powietrza na zdrowie, Krakowski Alarm Smogowy, Kraków.

Jędrychowski W., Majewska R., Mróz E., Flak E., Kiełtyka A., Oddziaływanie zanieczyszczeń powietrza drobnym pylem zawieszonym $i$ wielopierścieniowymi węglowodorami aromatycznymi w okresie prenatalnym na zdrowie dziecka. Badanie w Krakowie, Kraków, https://powietrze. malopolska.pl/wp-content/uploads/2018/03/Zanieczyszczeni a_powietrza_w_Krakowie_a_ zdrowie_dzieci.pdf, 4.08.2018.

Juda-Rezler K. (2006), Oddziaływanie zanieczyszczeń powietrza na środowisko, Oficyna Wydawnicza Politechniki Warszawskiej, Warszawa.

Judgment of the Court of Justice of the European Union, 5 April 2017, Commission v Republic of Bulgaria, Failure of a Member State to fulfil obligations - Environment - Directive 2008/50/ WE - Ambient Air, ECLI:EU:C:2017:267.

Judgment of the Court of Justice of the European Union, 22 February 2018, Commission v Poland, Failure of a Member State to fulfil obligations - Directive 2008/50/WE - Ambient Air, ECLI:EU:C:2018:94.

Kamiński J. W., Strużewska J. (2018), Szarość nieba, „Academia,” journal of Polish Academy of Sciences, special issue Smog, 2/5/2018.

Kozłowska-Szczęsna T., Krawczyk B., Kuchcik M. (2004), Wpływ środowiska atmosferycznego na zdrowie i samopoczucie czlowieka, Polska Akademia Nauk, Instytut Geografii i Przestrzennego Zagospodarowania im. S. Leszczyckiego, Warszawa.

Krzyżanowski M. (2016), Wpływ zanieczyszczenia powietrza pyłami na uktad krążenia i oddychania, „Lekarz wojskowy”, tome 94, vol. 1.

Mazurek H. (2018), Smog. Zagrożenie dla zdrowia czy moda na ekologię?, ITEM Publishing, Warszawa.

Mysłowski J. (2011), Zanieczyszczenie powietrza przez pojazdy samochodowe, Wydawnictwa Komunikacji i Łączności WKŁ, Warszawa.

Najwyższa Izba Kontroli (2014), Informacja o wynikach kontroli. Ochrona powietrza przed zanieczyszczeniami, Warszawa. 
Nowa encyklopedia powszechna PWN (1997), tome 3, Wydawnictwo Naukowe PWN, Warszawa.

OECD (2012), OECD Environmental Outlook to 2050. The Consequences of Inaction, OECD Publishing, OECD iLibrary, https://read.oecd-ilibrary.org/environment/oecd-environmental-outlookto-2050_9789264122246-en\#page1, 23.07.2018.

Pałasz J. W. (2016), Niska emisja ze spalania węgla i metody jego ograniczania, Wydawnictwo Politechniki Śląskiej, Gliwice.

Poskrobko B., Poskrobko T. (2012), Zarządzanie środowiskiem w Polsce, Polskie Wydawnictwo Ekonomiczne, Warszawa.

Raport z wdrażania dyrektywy Parlamentu Europejskiego i Rady nr 2001/81/WE z dnia 23 października w sprawie krajowych pułapów emisji niektórych zanieczyszczeń powietrza atmosferycznego za rok 2009 i projekcja emisji na rok 2010 (2011), Rzeczpospolita Polska, Warszawa.

Reizer M. (2016), Co to jest pyt zawieszony?, in: Pyty drobne w atmosferze. Kompendium wiedzy o zanieczyszczeniu powietrza pyłem zawieszonym $w$ Polsce, eds. K. Juda-Rezler, B. Toczko, Główny Inspektorat Ochrony Środowiska, Warszawa.

Szczeklik A., Gajewski P. (2014), Interna Szczeklika 2014. Podręcznik chorób wewnętrznych, Medycyna Praktyczna, Kraków.

Ustawa z dnia 27 kwietnia 2001 Prawo ochrony środowiska, Journal of Laws from 2001, No. 62, item 627.

Wojewódzki Inspektorat Ochrony Środowiska w Gdańsku (2015), Wpływ ozonu i promieniowania UV na zdrowie człowieka, https://www.gdansk.wios.gov.pl/wios/aktu alnosci/23-a2015/327-wplywozonu-i-promieniowania-uv-na-zdrowie-czlowieka.html, 6.08.2018.

Wojtalik M. (2012), Kiedy powietrze zabija. 65 lat temu wielki smog $w$ Londynie doprowadzit do śmierci 12 tys. osób, 5.12.2012, „Newsweek,” http://www.newsweek.pl/swiat/wielki-smog-wlondynie-1952-londynski-smog-zabil-w-1952-12-tysiecy-osob,99276,1,1.html, 17.07.2018.

World Health Organization (1946), Constitution of the World Health Organization, New York, http:// apps.who.int/gb/bd/PDF/bd47/EN/constitution-en.pdf?ua=1, 8.08.2018.

World Health Organization (2006), WHO Air quality guidelines for particulate matter, ozone, nitrogen dioxide and sulfur dioxide. Global update 2005. Summary of risk assessment, Geneva.

\section{Stan powietrza w Unii Europejskiej a jakość życia Europejczyków}

\section{Streszczenie}

Celem artykułu jest przedstawienie wpływu zanieczyszczeń powietrza na jakość życia mieszkańców Unii Europejskiej. Przy wykorzystaniu metody analizy instytucjonalno-prawnej oraz ilościowej podjęto próbę odpowiedzi na następujące pytania badawcze: 1) stężenia których zanieczyszczeń przekraczają normy wyznaczone na poziomie unijnym?; 2) jakie są przyczyny ponadnormatywnych stężeń zanieczyszczeń?; 3) jaki jest wpływ zanieczyszczeń na zdrowie Europejczyków? W toku przeprowadzonych rozważań wykazano, że jakość życia Europejczyków obniżana jest przez utrzymujące się, ponadnormatywne stężenia zanieczyszczeń powietrza, na które ekspozycja wiąże się z gorszym samopoczuciem, licznymi chorobami układu oddechowego, krążenia, nerwowego, a nawet rozrodczego, a także ze zwiększoną umieralnością i skróceniem oczekiwanej długości życia. W Unii Europejskiej oszacowana liczba przedwczesnych zgonów w 2014 r. w wyniku narażenia na pył drobny, ozon i dwutlenek azotu wyniosła 487,600. Jak wynika z przeprowadzonej analizy, najlepsze warunki życia, biorąc pod uwagę jakość powietrza, panują w Finlandii, Irlandii i Szwecji.

Słowa kluczowe: bezpieczeństwo ekologiczne, bezpieczeństwo środowiskowe, bezpieczeństwo zdrowotne, jakość życia, jakość powietrza, Unia Europejska 